\title{
THE HERITAGE OF EUROPEAN INTERNATIONAL SOCIETY IN MULTIDIMENSIONAL PEACE OPERATIONS: LIBERIA AS A CASE STUDY
}

\author{
A HERANÇA DA SOCIEDADE INTERNACIONAL EUROPEIA NAS OPERAÇÕES DE \\ PAZ MULTIDIMENSIONAIS: A LIBÉRIA COMO ESTUDO DE CASO
}

Matheus de Abreu Costa Souza

\begin{abstract}
The present paper has as its central objective to analyze United Nations (UN) peace operations as a form of creating post-conflict States that carries a series of institutions that underpins what is understood as the International Society, firstly consolidated by European states in previous centuries. I rely on English School's historical perspective on International Society in order to demonstrate the transmission of certain institutions through multidimensional peace operations, briefly exposing the United Nations Mission in Liberia (UNMIL) case. By analyzing some primary documents concerning the mission that took place in Liberia, it is possible to infer that UN multidimensional peace operations promotes institutions built within a European and Western international order.
\end{abstract}

Key words: English School; International Society; Peace Operations; United Nations; UNMIL.

Resumo

O presente trabalho tem como objetivo central analisar as operações de paz da Organização das Nações Unidas (ONU) como uma forma de criar Estados pós-conflito que carregam uma série de instituições que sustentam o que é entendido como Sociedade Internacional, primeiramente consolidada pelos europeus nos séculos anteriores. O artigo baseia-se na perspectiva histórica da Escola Inglesa sobre a Sociedade Internacional, a fim de demonstrar a transmissão de certas instituições através das operações de paz multidimensionais, expondo o caso UNMIL. Ao analisar alguns documentos primários relativos à missão que ocorreu na Libéria, é possível inferir que as operações de paz multidimensionais da ONU promovem instituições construídas dentro de uma ordem internacional europeia e ocidental.

Palavres Chave: Escola Inglesa; Sociedade Internacional; Operações de Paz; Nações Unidas; UNMIL.

\section{Introduction}

The present paper is based on the perspective of the English School theorists about the existence of an international society ${ }^{1}$ throughout the history of international relations. English School scholars share the idea that this society is composed of some values and objectives that are common among all its

\footnotetext{
${ }^{1}$ The term "international society" shall be used with lower case letters when referring to the concept designed by the English School theorists. However, when it is referred to a specific time-space society, like the European International Society, it will be used with capital letters.
} 
members, such as the international maintenance of a dominant political organization. However, this society is shaped throughout history, and it is from this historicist perspective that this article relies on, since the central objective is to identify the legacies of an earlier international society (European International Society ${ }^{2}$ ) to the Global Society of nowadays.

The main question that guides this piece is which European International Society institutions were inherited by the Global Society through the United Nations peace operations addressed to post-conflict societies? The hypothesis for the previous question is that the states that had emerged in a context of collapse of the European colonization inherited from the European Society a series of norms, values and common institutions, for example, the political organization based on a model of Modern State, and thus incorporate these values to enable their membership in international society. Based on this initial hypothesis, the article aims to identify some of these inheritances from the European International Society that are reaffirmed by policies adopted within the United Nations multidimensional peace operations framework, since the mechanism promotes a Western perspective on notions such as the "State", "Development" and "Protection of Fundamental Rights". It is also expected the presence of ideas leading to "democracy" in multidimensional operations guidelines, emphasizing the need for political reconstruction in post-conflict environments.

To test the hypothesis of this paper, I will rely on a historical-oriented analysis to understand the transition between different international societies, and to assess whether there is an inheritance that is aggregated into the contemporary one. In addition to the method mentioned above, I will carry a documentary analysis of primary sources over the multidimensional peace operations, aiming to identify their purposes and how they contribute to the establishment of norms, values, and objectives designed by the European International Society. Finally, I will conduct a brief case study of the United Nations Mission in Liberia (UNMIL) aiming to identify if there is an attempt to structure the country based on values previously shared by the European International Society and perpetuated in today's Global Society.

\section{The European International Society and its influences on the Global Society}

As announced before, the present paper mobilizes some understandings of English School Theory to comprise the existing dynamics on the international environment. Thus, this section aims to provide a theoretical framework that comprises the conceptualization of "international society" based on the English School perspective. From this initial conceptualization, the characteristics of the European International Society will be addressed, seeking to identify their influence in the current international society.

\footnotetext{
${ }^{2}$ It is relevant to mention that the term "European" is referred to the West Europe empires that dominated most of the continent in earlier centuries, thus east Europe countries were not included at that time.
} 
English School theorists' main purpose is to overthrow the realist argument that anarchy presupposes a tendency to chaos due to the lack of a central authority to rule and shape states' relations and ties. To do so, the theory, based mostly on Bull (2002) in its early years, argues that anarchy can be a sphere where states can cooperate and mold not only a state system 3 , but also an international society. Based on a historicist perspective, English School scholars defend that in the history of international relations, states did create an international society that can be identified when

\footnotetext{
(...) a group of states, conscious of certain common interests and common values, form a society in the sense that they conceive themselves to be bound by a common set of rules in their relations with one another, and share in the working of common institutions (Bull, 2002: 13)
}

As we can identify in the previous affirmation, English School includes variables such as common interests, shared rules, values and norms to understand States' interaction within international sphere. Those variables are a relevant body of English School theory due to the fact that states mobilization in an international society can be understood only if we consider more than did the realists in their extremely rationalized perspective (Bull, 2002). Given the relevance of ideational variables for English School theorists, it is important to understand and identify what are the values that makes states feel connected in their relationship. Bull (2002) argues that

\begin{abstract}
(...) they regard themselves as bound by certain rules in their dealings with one another, such as that they should respect one another's claims to independence, that they should honor agreements into which they enter, and that they should be subject to certain limitations in exercising force against one another. At the same time they operate in working of institutions such as the forms of procedures of international law, the machinery of diplomacy and general international organizations, and the customs and conventions of war (Bull, 2002: 98)
\end{abstract}

Bull's (2002) perspective can be identified when he defends that States do have a shared perception over the maintenance of some elementary objectives ${ }^{4}$, considered as extremely relevant to enable cooperation and order at the international level, moving states away from the Hobbesian condition that shaped most realist assumptions. According to Bull (2002), there are three fundamental objectives shared among States, thus such units consciously seek to protect it in the international society that they compose. The first elementary objective is related to the states maintenance in international environment, since the members of an international society want to keep themselves as the dominant form of political entity. Secondly, Bull (2002) argues that states usually tend to base their relations on the "pacta sunt servanda" perspective, which is a law term that reaffirms the role of commitment among the parties in

\footnotetext{
3 Bull (2002) identifies that international systems exists "when two or more states have sufficient contact between them, and have sufficient impact in one another's decisions, to cause them to behave - at least in measure - as parts of a whole" (Bull, 2002: 9). The definition does not comprise the perspective of a common knowledge of the relevance of rules, values and norms internationally established between States, being this the difference between the definitions of societies and systems of states. 4 These are the more elementary objectives of the international society, which do not mean that they do not seek other objectives. However, the guarantee of the elementary ones is what makes possible for States to pursue new objectives.
} 
honoring signed agreements, treaties and words, thus states seek to ensure that agreements established between there are stable and complied. Lastly, the third objective is the mutual recognition of states' external sovereignty. All three objectives are closely related to states will of mitigating uncertainty that is part of the anarchy they live in, thus establishing international elementary boundaries for their actions can lead them towards "peace maintenance"

English School's argument about international society is charged with strong historicism. The theory defends that it is possible to identify throughout history the existence of many types of international societies, which varied in terms of whose were their members and shared specific and often distinct characteristics, but which, somehow, always seek to protect the elementary objectives mentioned above (Bull, 2002; Buzan, 2014). In order to fulfill the general objective of the article - to identify the inheritances of the European International Society that can be found in multidimensional peace operations -, I will present on this section the characteristics of that society, consolidated mainly between the sixteenth and nineteenth centuries ${ }^{6}$.

Bull (2002) and Watson (1992) argues that in pre-European society, named the Christian International Society, Christianity and religious values were key aspects for the maintenance of ties within political leaders, entities and people. However, in this context, there was no clear definition of which were the boundaries that should not trespassed by political communities during the process of empires expansion, thus the absence in such context had triggered a series of conflicts among Europeans. This society, therefore, sought an alternative not only to combat religious and expansionist conflicts in Europe, but also to avoid the Habsburg Empire's plan of hegemony in the old continent.

It is in this context of attempted expansion of the Habsburg Empire that the princes and legal guardians of the European empires met several times to seek alternatives to promote an order among Europeans. The result of these meetings was the 1648 Treaty of Westphalia, which consolidated a series of new rules, institutions and norms that still shapes States' relations under anarchy. An example of Westphalia's relevance is the idea that societies and nations should be organized under the aegis of a political and bureaucratic framework - the State. It is also through the Treaty of Westphalia that the right of sovereignty was recognized among European newly born states at that time. Therefore, we can infer that there is a change of the Habsburg logic of imperial expansion, insofar as there were a mutual recognition of the sovereignty of other political communities (Watson, 1992).

\footnotetext{
5 It is necessary to understand that, for Bull (2002), the idea of peace maintenance is not related to Kant's idea of Perpetual Peace. Bull (2002) defends that the "(...) absence of war among member states of international society as the normal condition of their relationship" (Bull, 2002: 17). Thus, when there are threats to this peace, war is authorized by international society for a just cause. For more information on just war, see chapter 4 , by Bull (2002).

${ }^{6}$ It is worth noting that it is in the eighteenth century that we have, in a more consolidated way, what are the characteristics of the European International Society. However, it is recognized that the previous period influenced the direction of this society, as in the case of the Treaty of Westphalia.
} 
By consolidating the notions of "nation-state" and "sovereignty" in Westphalia, Europeans had defined the immediate members of their international society: sovereign nation-states. From this clearer delimitation of which members were part of this society, new ways of thinking the relationships between the members emerged. An example of this is after the consolidation of the ideals envisaged in Westphalia, there was also a change in the sphere of law. Rather, there was an idea of "natural law", backed by Christian values and directed towards individuals. With the gradual consolidation of the European International Society, this logic was replaced at the international level by what was known at the time as the Law of Nations, since it was "(...) the science of the rights which exists between Nations or States, and of the obligations corresponding to these rights" (Vattel apud Bull, 2002: 33). It is noted, then, that this Law of Nations, which was later named as international law, established the limits of State's actions in an environment that was recognized as anarchic and anti-hegemonic (Bull, 2002; Watson, 1992).

It is possible to affirm that the Treaty of Westphalia influenced directly in the consolidation of other common institutions between Europeans, especially along the eighteenth century. It is argued that Westphalia's treaty influenced the emergence of central institutions that still exist and continues to be relevant to comprehend international society and its dynamics in the contemporary world. One of these institutions is the International Law that delimits the rules of states' action under anarchy. The respect of sovereignty legitimacy was another institution that appeared initially with Westphalia and, over the years, consolidated not only as a rule but also as a principle. Other institution developed by Europeans was diplomacy, which was considered as a civilized way to disputes resolution between the members of international society. Lastly, European International Society consolidated another principle, which is the limitation on the use of force, in other words, states recognized the social, humanitarian and economic harms for those involved in wars (Watson, 1992; Bull, 2002). However, the institutions aforementioned are only part of the institutions that states share nowadays, thus these are only examples of primary institutions that took place in the European International Society. It is relevant then to define what is being defined as primary institutions, which are:

\footnotetext{
Durable and recognized patterns of shared practices rooted in values held commonly by the members of interstate societies, and embodying a mix of norms, rules and principles. In some cases these shared practices and values may be extended to, and accepted by, non-state actors (Buzan, 2004: 181).
}

By the definition exposed above, it is possible to conclude that primary institutions are durable and they shape not only the relations between States but also the international society itself. These institutions are defining a structure and modifying them will lead to the re-signification of the international system or society ${ }^{7}$ (Buzan, 2004). Besides the primary institutions, authors of the English School also defend that

\footnotetext{
7 An example of this is: if international law does not exist, it will lead to a re-signification of the relationship between states, since there will be no international normative framework regulating interaction in this anarchic environment. Thus, in general, what
} 
other institutions, denominated as secondary, emerged from the interaction among the states, making contemporary international society even more complex in comparison with the European International Society. These secondary institutions are smaller regulatory and normative features that emerged from the necessity of fortifying primary institutions. Towards a more inclusive international society, Buzan (2004) also modifies the previous scheme of primary institutions by including, for example "equality of people". In the author's point of view, equality - at least from a formal perspective - became a relevant institution within Global International Society, given the fact that the new members of international society required equal rights for their political communities. A more complex scheme over primary and secondary institutions can be summarized in the Table 1 below.

Table 1-Contemporary International Institutions

\begin{tabular}{|c|c|c|}
\hline \multicolumn{2}{|c|}{ Primary Institutions } & \multirow{2}{*}{$\begin{array}{l}\text { Secondary Institutions } \\
\text { (examples of) }\end{array}$} \\
\hline Master & Derivative & \\
\hline \multirow[t]{2}{*}{ Sovereignty } & Non-intervention & UN General Assembly \\
\hline & International law & Most regimes, ICJ, ICC \\
\hline Territoriality & Boundaries & Some PKOs \\
\hline \multirow{4}{*}{ Diplomacy } & Bilateralism & Embassies \\
\hline & Multilateralism & United Nations \\
\hline & & Conferences \\
\hline & & Most IGOs, regimes \\
\hline \multirow{3}{*}{$\begin{array}{l}\text { Great power } \\
\text { management }\end{array}$} & Alliances & NATO \\
\hline & War & UN Security Council \\
\hline & Balance of power & \\
\hline \multirow[t]{2}{*}{ Equality of people } & Human rights & UNHCR \\
\hline & $\begin{array}{l}\text { Humanitarian } \\
\text { intervention }\end{array}$ & \\
\hline \multirow[t]{3}{*}{ Market } & Trade liberalisation & $\begin{array}{l}\text { GATT/WTO, MFN } \\
\text { agreements }\end{array}$ \\
\hline & Financial liberalisation & IBRD, IMF, BIS \\
\hline & Hegemonic stability & \\
\hline \multirow[t]{3}{*}{ Nationalism } & Self-determination & Some PKOs \\
\hline & Popular sovereignty & \\
\hline & Democracy & \\
\hline \multirow{3}{*}{$\begin{array}{l}\text { Environmental } \\
\text { stewardship }\end{array}$} & Species survival & CITES, UNFCCC, \\
\hline & Climate stability & Kyoto Protocol, IPCC, \\
\hline & & Montreal Protocol, etc. \\
\hline
\end{tabular}

Source: Adapted from Buzan, 2014: 187.

Looking at the secondary institutions of Table 1, we can identify some which are inheritances strictly of the European International Society. One example that deserves to be mentioned, because of its relevance to understand the United Nations peace operations, are the institutions constructed in parallel

Buzan (2004) proposes is that the change in these primary institutions corroborates to more extensive changes in international societies. 
with the advance of the ideals of the French Enlightenment, which spread rapidly throughout Western Europe in the $18^{\text {th }}$-century. The Modern State at that time had rights and, especially, duties towards its people, since protecting the nation was a sine qua non condition for states' existence (Watson, 1992). Back then, the notions of liberty, equality and fraternity, which were the motto of French Revolution, shaped the primary institutions and resulted in the emergence of secondary institutions as well. This perception also influences what were conceived as fundamental human rights ${ }^{8}$, which still exists today within the framework of the United Nations.

In general terms, Watson (1992: 203) makes a reflection that helps to understand the European International Society, affirming that "The eighteenth-century European commonwealth was a sovereigns' club, and international law was the rule book of the club's independent and juridical equal members". We can conclude that this society was composed by states, guided by common objectives (the elementary ones), that were guaranteed by the establishment and respect of institutions, formal or informal, developed by its members (Bull, 2002; Watson, 1992). Watson (1992) argues that the rules shaped by Europeans at that time are still valid to comprise the international politics in Global International Society nowadays. States remain the main actors and base their interaction on the institutions that were previously created and cited above, like diplomacy, regulation of the use of force, sovereignty mutual respect and so on. It is even more interesting to note that there is an inheritance of this society for a Global International Society, as a result of the processes of decolonization and the inclusion of new sovereign States, since they are inserted in an order that was historically shaped by European States.

Although most of the primary institutions have been maintained, what was broken in this transition period from the European International Society to the Global International Society were not the institutions consolidated by Europeans, but the idea of an international society that was culturally close, due to the insertion of members that are culturally distant. However, what is argued in Watson (1992) and Bull (2002) is that there is always a continuum between international societies, and that inheritances are recurrent in this process, because it is unlikely to happen an abandonment of all primary institutions that have been historically consolidated. In this case, inheritances are European, and they are perpetuated among the new members, since the European standards of political organization, provision of fundamental rights and the maintenance of the order built throughout the history of Europe are prerequisites for the admission of new members to this Global International Society. Thus, it was necessary for the states formed in the processes of decolonization to "(...) met a standard of civilization laid down by the Europeans" (Bull, 2002: 32).

Watson (1992), using the historical-comparative-method, observes that

\footnotetext{
${ }^{8}$ Although shaped by the 1948 Universal Declaration of Human Rights (UDHR), it is a result of an earlier process of promoting respect for fundamental freedoms that occurred mainly in Europe and Western countries (Piovesan, 2013).
} 


\begin{abstract}
The evidence therefore indicates that the formal rules and institutions of a society of states, and especially its assumptions and codes of conduct are formed within the matrix of a single culture. When states belonging to different cultures are involved in the pressures of the same system, regulatory machinery will be devised and adjusted to manage their relations. If a society of states becomes dominant within a wider system, as was the case with the European society in the nineteenth century, other states in the system can become members of the society or be associated with it, provided they conform with its rules and assumptions, perhaps with marginal modifications (Watson, 1992: 259).
\end{abstract}

Before proceeding, it is relevant to make a reservation to the English School thinking. Theorists concede that international society does not presuppose substantial justice, but rather formal justice, since post-colonial states, which are members of the Global International Society, have not participated in the construction of primary institutions, but this fact does not exclude independent states' interests in the elementary goals. In this sense, post-colonial states eventually accepted the European institutions to get rid of European colonization in a first moment, but now they - voluntarily or not - tend to share the same rules and norms, and tend to respect and promote the primary institutions, even by performing small adjustments, or "marginal modifications" in Watson's words. English School, then, recognize that the international order is not always fair with post-colonial and third world states. Therefore, designing the international society and its institutions also depends on power relations, moving the concept of international society away from a Kantian cosmopolitan perspective, which would mean that states do cooperate only by a humanitarian perspective.

Based on the theoretical framework exposed in this section, the main idea of this paper is to establish a parallel between the primary institutions inherited by the Global International Society, such as the notions of state, human rights, democracy and others, in order to understand how they are transmitted to post-conflict societies that had received UN multidimensional peace operations. My main idea is to demonstrate those operations guidelines and practices corroborate with the rules, values and norms built during the European International Society. With this in mind, the next section presents the UN's peace operations in general, focusing on the multidimensional missions, that are more complex and multitasking.

\title{
Multidimensional peace operations: reflecting Western-based institutions
}

The United Nations Charter designated to the United Nations Security Council (UNSC) powers and responsibilities with regard to the maintenance of peace and collective security. However, by analyzing the document, it is noted that it leaves a gap on how security can be maintained in practice, what mechanisms are beyond the UNSC, and how members of this committee should act in threatening situations (UN, 1945). The United Nations peace operations have even emerged in view of the regulatory loophole left by the Charter (Uziel, 2015). 
These operations are ad hoc mechanisms and at an early stage consisted of observers that had only to monitor ongoing conflicts. The first generation of such missions had three central objectives: (i) to monitor the establishment of peace in conflict situations, observing the process of negotiation between the parties involved; (ii) to promote respect for borders; (iii) to support both parties politically, in a neutral manner, with the aim of building a fertile environment conducive to the implementation of these operations. The missions with the purposes cited above are considered as traditional peace missions. In order not to be interpreted as unilateral interventions, traditional missions were implemented at a time when there was already a prospect of a conflict resolution, so the UN could fulfill its basic monitoring function, avoiding engagement in complex functions to resolving conflicts (Bellamy et al, 2004; Aksu, 2003)

However, as peace operations became institutionalized, the UN's framework also has evolved to follow such process of institutionalization. This institutionalization and acceptability among the UN's member states allows the evolution of peace operations, since they shared the idea that such mechanism could be a way of promoting collective security. Due to this shared opinion, each mission, especially after the 1990s, incorporated new goals and new ways of operationalizing peace operations authorized by the UNSC (Souza, 2017).

The end of a bipolar system also contributed to peace operations development, because during bipolarity, United States and Soviet Union individual interests stood out over the collective ones, freezing the UNSC (Uziel, 2015). By the end of the Cold War, there was a change in the logic of UN action in peace operations. Kenkel (2013: 128) observes that UN began to play an "[...] active involvement not only in "freezing" conflicts but in assisting the transition to peace". These operations were named multidimensional peace operations, insofar as the organization's objectives are more complex and it abandoned a position of merely observer (Bellamy et al, 2004).

The idea of a more complex and multidimensional peace operations first appeared in the 1992 "An Agenda for Peace" report, which was a recommendatory document made by the former Secretary General Boutros-Ghali, and were subsequently accepted by member states in General Assembly. The report aimed to rethink more effective ways to conduct peace operations in order to deal with the complexity of the internal conflicts that emerged at that time (UN, 1992). Boutros-Ghali stated, in the document preamble, the UN difficulty to deal with intrastate conflicts in post-colonial states, where he stated that in order to resolve such type of conflicts, the UN should promote human rights and social and economic development

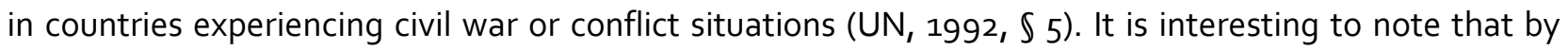
stressing the need of promoting human rights and social and economic development, the United Nations acts in favor of institutions firstly designed by Europeans, such as the human rights itself and shared notions about what economic development really is, notion that is often rooted in liberal institutions and assumptions, e.g. market liberalization. 
The report "An Agenda for Peace" also links the achievement of peace to the success in consolidating democracy and open forms of economic liberalization. Thus, peace could be reached only if a state experiencing conflict decides to adopt democratic and liberal economic institutions, which were all European-born institutions that seemed the only alternative for post-conflict states after the dominance of liberal assumptions, that prevailed in the 1990s, about how states should be internally organized. Indeed, according to the report, democracy would be a wise solution to solve intrastate conflicts that were usually based on ethnic, cultural and religious cleavages, due to the fact that the demands for power would be accommodated after the implementation of democratic institutions, which plays an important role on promoting inclusiveness of marginalized warring groups. Thus, by opening the economy, the state could be able to improve its people's livelihoods, mitigating dissatisfaction of societies with their respective governments (UN, 1992).

Therefore, if peace promotion is directly linked to democracy and market liberalization, the United Nations needed to be able to promote those in order to be effective in promoting international security. Thus, the UN and its member states had to broad the scope of peace operations in order to be able to cope with the vast array of functions institutionalized within "An Agenda for Peace", that were not commonly held in traditional missions. The new tasks ${ }^{9}$ of multidimensional peace operations are

\begin{abstract}
To seek to identify at the earliest possible stage situations that could produce conflict, and to try through diplomacy to remove the sources of danger before violence results; Where conflict erupts, to engage in peacemaking aimed at resolving the issues that have led to conflict; Through peacekeeping, to work to preserve peace, however fragile, where fighting has been halted and to assist in implementing agreements achieved by the peacemakers; To stand ready to assist in peacebuilding in its differing contexts: rebuilding the institutions and infrastructures of nations torn by civil war and strife; and building bonds of peaceful mutual benefit among nations formerly at war; And in the largest sense, to address the deepest causes of conflict: economic despair, social injustice and political oppression (UN, 1992, \$15).
\end{abstract}

The report has advanced in definitions and proposed divisions of tasks between peace operations in sight of the demands that were typologically distinct. The concepts of preventive diplomacy, peacemaking, peacekeeping and post-conflict peacebuilding were also crystallized within the organizational framework in order to specify which mechanism would be most appropriate for each context or occasion (UN, 1992, $\$ 20)$. All of them are quite relevant to understand peace process, albeit for the present article the most interesting mechanism to note is the term "post-conflict peacebuilding", defined in the report as an "(...) action to identify and support structures which will tend to strengthen and solidify peace in order to avoid a relapse into conflict" $(U N, 1992, \$ 21)$. The definition coincides with Secretariat's ideas that it would be necessary to construct a new environment for the newly independent states facing conflict situations. This new environment would certainly be a democratic and liberal one, organized by institutions inherited by European International Society. Thus, peacebuilding within the

9 Such tasks would be sustained by different mechanisms, but the most important for the present paper is the post-conflict peacebuilding one. 
United Nations context is understood as a mechanism that promotes (re)construction of certain institutions believed to be responsible for long-term peace, which would be ensured by the employment of a reform in economic, social and political sectors of post-conflict society (Nagakawa, 2016; Newman, 2013; Ryan, 2013; Paris, 1997; 2004).

In another article of the report, peacebuilding success is conditioned to the restoration of political institutions, process that should be assisted by the United Nations and its member states. Restoring institutions is a sine qua non condition for achieving long-term peace according to the report, albeit there is a focus on rule of law and democracy. In the article below, it is possible to identify a direct establishment of democracy, rule of law, and security as variables that can lead post-conflict states towards a peaceful society. In addition, the document indirectly promotes an idea of what is considered as "good governance", that seems to be a model filled with parameters that states must be in accordance to (UN, 1992). Thus, democracy and rule of law are some of the parameters, institutions that plays fundamental role in the Global International Society, albeit they were originally created by Europeans and later reinforced by other powerful states such as the US.

[...] support for the transformation of deficient national structures and capabilities, and for the strengthening of new democratic institutions. [...] There is an obvious connection between democratic practices - such as the rule of law and transparency in decision-making - and the achievement of true peace and security in any new and stable political order. These elements of good governance need to be promoted at all levels of international and national political communities (UN, 1992, \59)

The UN practices delineated in the report are closely related to a very particular concept and notion of how to capture peace in war-torn societies that were influent and somehow dominant within peace studies scholars. This idea is commonly referenced as "liberal peace", which basis its assumptions in two main arguments. The first argument that had once strengthened liberal peace notion is that liberal and democratic states do not wage on war each other, thus, the most appropriate model of state should include institutions capable of sustaining democracy and political and economic liberalism (Mac Ginty, 2006). The second basis for liberal peace argument is the overemphasis attributed - by states, policymakers and most international organizations - to liberalism and democracy in a post-Cold War era that represented capitalist triumph over socialism. Hence, in the 1990s, being liberal and democratic seemed to be the only option for independent states, aspect that obviously influenced the way that UN conceived its peacebuilding concept and practices (Schulenburg, 2017; Newman, 2013; Paris, 2004; Ryan, 2013; Firchow, 2016). As well observed by Yoshito Nagakawa (2016), the United Nations model of peacebuilding is influenced by the perspective of liberal peace and it bases on

\footnotetext{
"(...) the following narratives: an open economy leads to economic development through growth; economic development interacts with the formation, maintenance and consolidation of democracy; and both democracy and economic development respectively contribute to forming a liberal form of peace". (Nagakawa, 2016: 50).
} 
Therefore, multidimensional peace operations tend to promote a specific kind of states' (re)construction, resembling to the European-based model of what is a state and the good governance that it may follow, notions that had emerged in the European International Society as argued before. There is an optimism that by strengthening institutions such as democracy, rule of law, market, and others, it is possible to capture the essence of peace (Newman, 2013; Ryan, 2013; Firchow, 2016). However, relevant is to note that liberal peace has been strongly challenged by researches that criticize ${ }^{10}$ the United Nations performance in post-conflict societies, arguing that the process occurs basically in a top-down way, tending to be non-integrative with local societies (Mac Ginty, 2006; Mac Ginty, 2011; Mac Ginty and Richmond, 2013) Such critics are quite valid and pertinent and I actually tend to agree with them. Although, this article intends to demonstrate the European International Society influence on how the world politics is being shaped by the interventionist missions led by the United Nations. Thus, it deviates from the dilemmas involving such missions, albeit it exposes how top-down and non-local multidimensional peace operations tend to be.

By performing this analysis of the "An Agenda for Peace" report, document that inaugurates UN's multidimensional peace operations, we can conclude that peace operations, whether consciously or not, are also ways of perpetuating primary and secondary institutions - that first appeared in Europe and later were gradually expanded and replicated by other states - in light of liberal peace ideals. Examples of such institutions are rule of law, democracy, liberalism, human rights, and sovereignty. Thereby, it is intended to illustrate this argument with an analysis of second mission that took place in Liberia - UNMIL - which assumed a multidimensional character.

\section{A brief case study of UNMIL (2003-2016)}

Before proceeding, it is necessary to provide reasons for why the Liberian case has been chosen to illustrate the main argument of this article - that United Nations a multidimensional peace operations (re)construct states based on institutions designed by the European International Society and its members. Firstly, Liberia is considered by United Nations as a successful case of multidimensional peace operation, hence such success means that UNMIL deployed in 2003 was effective in promoting their main task of rebuilding the state based on institutions inherited from the European International Society (argument discussed in the section above) (UNSC, 2012). Secondly, Liberia had received way more direct influence from the United States rather from Europeans, and even though Liberia was sooner or later (re)built in light of what Europeans considered as a state and the institutions that come with it, demonstrating the widespread capacity of European origin-based institutions in the Global International

${ }_{10}$ For deeper understanding on critical perspective of United Nations peacebuilding, I recommend the following articles and books: Mac Ginty (2006), Mac Ginty (2011), Mac Ginty and Richmond (2013), Paris (1997; 2004) and Sabaratnam (2017). 
Society. Thus, the case study will be held based on an evaluation of data available in primary documents signed within the UNSC concerning the authorization of UNMIL and the council declaration of its end in 2016.

Located in West Africa, Liberia is a country that, as briefly mentioned above, has a somewhat distinct history compared with other countries in Africa, since the state had not suffered intense domination of the European settlers and declared its independence in 1847 (Esteves; Carvalho, 2011). Although the country has not suffered from an intense European colonization, it has been under the command of the United States of America for a long period of its history. The Americans, led by a group of white abolitionists, created in 1822 an organization called the American Colonization Society (ACS), with the aim of forcing the emigration of blacks (freedmen after the abolition of slavery) to African countries, with the justification that, at that time, they would have the opportunity to return to their land, since they would not have great opportunities in US territory. ACS acknowledged, and made it clear, that they were returning with Africans to territories that had not yet reached the US' same stage of development (including basic infrastructure), and that it would be the role of these freed slaves to rebuild a country for them to live in (Carvalho; Esteves, 2011; NHC, 2008).

ACS, in this sense, withdraw from the responsibility to construct basic conditions before and while freed Afro-American slaves established themselves in the territory named as Liberia. Although, the US assumed the role of a settler, since it was their American representatives who carried out all the public administration in the Liberian territory in the first years after the America-Liberians arrival (NHC, 2008; Esteves; Carvalho, 2008). Akpan (2010) adds that American Liberians adopted Western patterns of culture, religion and political organization while they were in the US, and such aspects were not free from European influence, given the fact that the US was once a British colony. However, when the American Liberians first came to Liberia, their Western patterns of civilization and organization were questioned and challenged by the local population - very diverse in terms of culture, ethnicity, and religion at that time.

Liberia became independent in 1847, but many said that it would only be a formal independence due to the intense relations between Liberia and the United States. This dependence was criticized by the True Whigs party, which was the opposition party to the ruling party (the Republicans, made up of black settlers). Like the division between the parties, the population was also divided: on one side the settlers, who were mulatto and Americanized, on the other, the native Africans. This was an internal problem of the country that made policies, regardless of who was in power always favor a specific side, making the dispute for power also lead to the political instability of the country (Akpan, 2010). This political instability also affected the development of Liberian political institutions and influenced an outbreak of two civil wars, which required the presence of UN and its peace operations (Esteves; Carvalho, 2011).

Following this brief contextualization of the process of establishing Liberia as a state, an analysis of UNMIL (2003-2016) will be carried out. As mentioned earlier, Liberia underwent two civil wars. The first 
one broke out in the late 1980 s and the country demanded the establishment of a peace operation by the United Nations, named as United Nations Observer Mission in Liberia (UNOMIL), which lasted between 1993 and 1997 (Esteves; Carvalho, 2011). However, the mission was considered as traditional and only developed functions related to observation. Since the focus of the present paper is to analyze multidimensional peace operations as a form of socializing states in a global order influenced by European characteristics and institutions, this first mission will not be evaluated here. From now on, the focus will be on the second mission, implemented in 2003 after the resumption of hostilities between the belligerent parties, that was, in fact, a multidimensional and no more traditional peace operation (Matijascic, 2014).

In the second Liberian civil war, the United Nations Mission in Liberia (UNMIL) was set up with complex objectives. Liberia's context was marked by total discontent among the population, who later came to organize itself in militias, and Charles Taylor, President elected in 1997 when UNOMIL was present in the country. Liberian situation, at that time, was so complex that belligerent groups controlled much of Liberian territory, demonstrating government's inability in controlling its own territories. This situation demanded a much more complex mandate from the United Nations, consolidating, then, a multidimensional mandate (Esteves; Carvalho, 2011). What is intended is to evaluate how the mandate of UNMIL promoted not only the (re)construction of the country but also a (re)construction made in European standards of political organization that emerged in a context of establishment of the European International Society.

Among the general objectives of UNMIL, it is important to highlight the following: i) the protection of civilians; (ii) the promotion of democracy; (iii) the promotion of humanitarian assistance; (iv) the provision of humanitarian assistance; v) the reform of Justice and Security Institutions; vi) the promotion and protection of human rights (UNMIL, 2017). With the exception of humanitarian assistance and protection of civilians, all other mentioned UNMIL's goals are directly related to the promotion of specific institutions that Europeans had created within their international society, hence establish institutions to achieve justice, democracy and human rights happens to be in accordance of European notions about what is the role of Modern States in representing their nation(s).

If we turn our attention to the preamble clauses of the 2003 resolution authorizing the establishment of UNMIL, the UNSC clearly stated a concern with the promotion of human rights, pointing out "(...) the need for the continued operation of United Nations and other agencies' relief operations, as well as promotion and monitoring of human rights" (UNSC, 2003: 1). This statement reaffirms the commitment of the UN and its members in the promotion of a European-originated concept of human rights institutionalized within the organizational framework.

Additionally, the mandate that authorized the deployment of UN blue helmets in Liberia is emphatic by stating the need of the establishment of a transitional government and rule of law in the country. Thus, the kind of state that the multidimensional mission is seeking is a very specific one, based 
on democratic assumptions that are embedded in the notion of rule of law - that first appeared and spread within European International Society. The mandate then establishes a direct relationship between the promotion of long-term peace in the country and the rule of law, as we can identify by evaluating the passage below:

Mindful of the need for accountability for violations of international humanitarian law and urging the transitional government once established to ensure that the protection of human rights and the establishment of a state based on the rule of law and of an independent judiciary are among its highest priorities (UNSC, 2003: 4).

Regarding the (re)establishment of political institutions in the country, UNMIL also had to play a key role, since it would be necessary

(...) to assist the transitional Government, in conjunction with ECOWAS and other international partners, in reestablishment of national authority throughout the country, including the establishment of a functioning administrative structure at both the national and local levels (UNSC, 2003: 4).

(...) to assist the transitional government in conjunction with ECOWAS and other international partners in developing a strategy to consolidate governmental institutions, including a national legal framework and judicial and correctional institutions. (UNSC, 2003: 4).

It is noted with the previous passages the need to establish a "functional administrative structure", which in this case would be the (re)establishment of the State of Liberia and its ability to exercise sovereignty. This process would be completed when the country would be able to ensure and promote institutions that have had emerged in the European International Society, such as the rule of law, sovereignty, democracy, and human rights provision.

It is also possible to infer that UNMIL's mandate is concerned with economic development (based on liberalism), inasmuch as it affirms that "international community to consider how it might help future economic development in Liberia aimed at achieving long-term stability in Liberia and improving the welfare of its people" (UNSC, 2003: 5). Thus, as we can conclude by evaluating the aforementioned passage, the mandate entrench direct relationship between peace, economic development, and welfare, since development and economic openness perspective would help in this process of transition to peace, reinforcing the liberal narrative of peace.

UNMIL end was declared in 2016, but UNSC resolutions continued to stress the need to state and its stakeholders to keep promoting democracy, democratic elections and institution building and consolidation (UNSC, 2016a; 2016b). Throughout the above-mentioned two resolutions, a number of advances by the Government of Liberia in the period of UNMIL (2003-2016) were acknowledged within the UNSC, but there is also evidence of a concern for stability which, according to the resolutions, is conditional on the establishment of the rule of law, and significant progress has not yet occurred: 
support national reconciliation, expressing concern that the Government of Liberia has not demonstrated sufficient progress in this regard and encouraging the enhanced assistance of Member States and multilateral organizations (UNSC, 2016a)

This is a clear example that the consolidation of political and democratic institutions takes place gradually and will hardly be assimilated quickly when one does not have a pre-existing democratic culture. Another analysis that can be inferred is that peace operations also serve as parameters to identify those states that have assimilated (or not) the inheritances of the European International Society since the monitoring carried out by the committees involved in these operations also work with the Western notion of "good governance". This idea of promoting democracy and holding democratic and peaceful elections is also present in the various documents (in Liberia's case, both in the authorization of the mandate and in the resolution that ends UNMIL's activities) (UNMIL, 2017; UNSC, 2016a; 2016b).

In the resolution authorizing the end of UNMIL'S activities, advances in the establishment of Liberia as a modern, democratic and peaceful state were recognized by UNSC and its experts, and the country was considered able to retake the full exercise of its sovereignty:

\begin{abstract}
Affirming that the Government of Liberia bears primary responsibility for protecting all populations within its territory, stressing that lasting stability in Liberia will require the Government of Liberia to sustain effective and accountable government institutions, particularly in the rule of law and security sectors, including capable, professional, and efficient military, police and border security forces, and, in this regard, welcoming the relevant assistance of bilateral partners and multilateral organizations (UNSC, 2016b).
\end{abstract}

Thus, it is recognized the Liberian government's ability to resume the full exercise of its sovereignty, always stressing the need to maintain the good governance model originated in European International Society. To retake the general argument of this article, I conclude with this brief case study that multidimensional peace operations tend to prioritize some European institutions when reconstructing states, such as liberalism and democracy in order to allow post-conflict states to become part of the Global International Society of nowadays. By conducting this case study, I could reaffirm the hypothesis that even being a minority in the Global International Society, Europeans have built a model of state - replied by non-European states as well - that is not strongly challenged by other states nowadays and still guides world politics.

\title{
Conclusions
}

The idea of this article was not, at least in this initial research, to challenge the institutions that are left by Europeans as "inheritance" for the Global International Society. That is, particular views of democracy and human rights are strongly questioned here, but we may recognize that these institutions were consolidated under Eurocentric and Westernized lens. What I have tried to analyze is the transfer of Europeans-originated norms and rules via peace operations. Peace operations were thus put forward as a 
way of promoting the assimilation of models of "good governance" that had emerged in European societies, which is quite widespread among the UN member states.

By performing a documentary analysis of reports that institutionalized peace operations within the UN's normative framework, I conclude that multidimensional missions carry a specific model to try to achieve peace in war-torn societies. This model relates the missions' success to the establishment of primary and secondary institutions that were created in the European International Society. This corroborates with English School Theory idea that in periods of change between different international societies, there is a great possibility of a continuum, which is, is this case, the maintenance of most European-based institutions.

Finally, the Liberian shows that even states that did not suffer from intense European domain were sooner or later inserted in a structure shaped by the European States in their particular international society. In this case, the US was the first responsible for providing a basis for the establishment of the Liberian state in a European order, albeit the process had failed and it was necessary to establish a multidimensional peace operation to socialize the Liberian government under the aegis or Europeanoriginated rules, norms and institutions. Therefore, I could observe, by employing a documental analysis of UNMIL's mandates, the worries related to the establishment of a Modern State, and also the necessity to preserve the country's sovereignty, diplomacy, justice, equality, democracy and liberalism, all institutions (primary or secondary) designed by the Europeans. Evaluating whether such institutions contributes to global peace will be then a focus for my future researches.

* Artigo recebido em 24 jun 2018, aprovado em 10 set 2018.

\section{Bibliography}

Akpan, Monday. Libéria e Etiópia, 1880-1914: a sobrevivência de dois Estados africanos. In Boahen, Albert (Ed.), História geral da África VII: África sob dominação colonial, 1880-1935. $2^{\text {a }}$ ed. Brasília: Unesco, 2010.

Aksu, Esref. The United Nations, intra-state peacekeeping and normative change. Manchester: Manchester University Press, 2003.

Bellamy, Alex; Willians, Paul; Griffin, Stuart. Understanding Peacekeeping. Cambridge: Polity Press, 2004. Bull, Hedley. The Anarchical Society: A study of Order in World Politics. 3rd ed. London: Palgrave Macmillan, 2002. 
Buzan, Barry. From International to World Society? English School Theory and the Social Structure of Globalization. Cambridge: Cambridge University Press, 2004.

Buzan, Barry. An Introduction to the English School of International Relations. Cambridge: Polity Press, 2014 .

Esteves, Paulo and Souza, Letícia. A Libéria e a construção do nexo entre segurança e desenvolvimento. Revista Brasileira de Política Internacional, 2011, 54(2): 22-45.

Firchow, Pamina. Engaging the Liberal Peace Piradigm: The Case of Rotary International. In: Firchow, Pamina; Anastasiou, Harry (Eds.). Practical Approaches to Peacebuilding: Putting Theory to Work. Boulder and London: Lynne Rienner Publishers, 2016.

Kenkel, Kai. Five generations of peace operations: from the "thin blue line" to "painting a country blue". Revista Brasileira de Política Internacional, 2013, 56(1): 122-143.

Mac Ginty, Roger. No War, No Peace: The Rejuvenation of Stalled Peace Process and Peace Accords. Basingstoke: Palgrave Macmillan, 2006.

Mac Ginty, Roger. International Peacebuilding and Local Resistance: Hybrid Forms of Peace. Basingstoke: Palgrave Macmillan, 2011.

Mac Ginty, Roger; Richmond, Oliver. The Local Turn in Peace Building: a Critical Agenda for Peace. Third World Quarterly, v. 34, n. 5, 2013, pp. 763-783.

Matijascic, Vanessa. Peacebuilding e as Nações Unidas. In Matijascic, Vanessa (Ed.), Operações de manutenção de paz nas Nações Unidas: reflexões e debates. 1st ed. São Paulo: Editora Unesp, 2014.

Nagakawa, Yoshito. Deliberative Peacebuilding in East Timor and Somaliland. 2016. 329f. Tese (Doutorado) - PhD pelo Humanitarian and Conflict Response Institute, Manchester University,

$\begin{array}{lcc}\text { Manchester, } & 2016 . & \text { Disponível } \\ \text { https://www.escholar.manchester.ac.uk/api/datastream?publicationPid=uk-ac-man- }\end{array}$ scW:305723\&datastreamld=FULL-TEXT.PDF>. Acesso em: 14 jun. 2018.

Newman, Edward. The International Architecture of Peacebuilding. In: Mac Ginty, Roger (Ed.). Routledge Handbook of Peacebuilding. Abingdon and New York: Routledge, 2013.

NHC. Emigration \& Colonization: The Debate Among African Americans, 1780s-186os. USA: North Carolina, 2008.

Paris, Roland. Peacebuilding and the Limits of Liberal Internationalism. International Security, 1997, 22(2): pp. 54-89.

Paris, Roland. At War's End: Building Peace after Civil Conflict. Cambridge: Cambridge University Press, 2004 .

Piovesan, Flávia. Direitos humanos e o direito constitucional internacional. 14th ed. São Paulo: Saraiva, 2013.

Ryan, Stephen. The Evolution of Peacebuilding. In: Mac Ginty, Roger (Ed.). Routledge Handbook of Peacebuilding. Abingdon and New York: Routledge, 2013.

Sabaratnam, Meera. Decolonising Intervention: International Statebuilding in Mozambique. London: Rowman \& Littlefield International, 2017. 
Schulenburg, Michael. On Building Peace: Rescuing the Nation-State and Saving the United Nations. Amsterdam: Amsterdam University Press, 2017.

Souza, Matheus. Institucionalizando a exceção: Uma análise da evolução das operações de paz das Nações Unidas. Paper presented at 6th Encontro Nacional da Associação Brasileira de Relações Internacionais, 2017, http://www.encontro2017.abri.org.br/resources/anais/8/1499730206_ARQUIVO_ABRIMatheusdeAbreuCostaSouza.pdf, Last accessed September 20, 2017.

UN. Carta das Nações Unidas. San Francisco: 1945, http://www.un.org/en/charter-unitednations/index.html, Last accessed August 20, 2017.

UN. Secretary-General resolution A/47/277, An agenda for peace, from 17 June 1992. [s.I.]: UN Documents, 1992, http://www.un-documents.net/a47-277.htm, Last accessed August 20, 2017.

UNMIL. UNMIL mandates. New York: United Nations, 2017, https://www.un.org/en/peacekeeping/missions/unmil/mandate.shtml, Last accessed August 22, 2017.

UNSC. 6830th Meeting. New York, September 11, 2012, http://www.un.org/press/en/2012/sc10758.doc.htm, Last accessed August 14, 2017.

UNSC. Security Council resolution 1509 (2003), from 19 September 2003. New York: United Nations, 2003, https://www.un.org/en/ga/search/view_doc.asp?symbol=S/RES/1509(2003), Last accessed August 21, 2017.

UNSC. Security Council, adopting resolution 2308 (2016), extends mandate of Liberia Peacekeeping Mission until year's end, mantains troop levels. New York: United Nations, 2016a, https://www.un.org/press/en/2016/sc12517.doc.htm, Last accessed: Last accessed August 20, 2017.

UNSC. Security Council terminates sanction regime on Liberia, unanimously adopting resolution 2288 (2016). New York: United Nations, 2016b, http://www.un.org/press/en/2016/sc12373.doc.htm, Last accessed August 20, 2017.

Uziel, Eduardo. O Conselho de Segurança, as Missões de Paz e o Brasil no Mecanismo de Segurança Coletiva das Nações Unidas. 2nd ed. Brasília: Fundação Alexandre Gusmão, 2015.

Watson, Adam. The Evolution of International Society: a comparative historical analysis. London and New York: Routledge, 1992. 